\title{
UNIVERSITY AND CITY MARKETING - THE CASES OF POZNAŃ, WROCŁAW AND KRAKÓW. MODEL APPROACH
}

\author{
KAMIL GLINKA \\ Institute of Political Sciences, University of Wrocław, \\ ul. Koszarowa 3, Wrocław, Poland \\ E-mail address: kamil.glinka1@wp.p1
}

(c)

\begin{abstract}
The analysis focuses on the functional connection between university marketing and city marketing. Therefore, the main aim of the article is to reconstruct the model of marketing cooperation of Poznań, Wrocław and Kraków and their biggest universities: the Adam Mickiewicz University, the Wrocław University of Technology and the Jagiellonian University. The use of three methods (case study, comparative analysis and content analysis) as well as the authorial, five-element model allows one to measure the level of the institutionalization of the cooperation. The choice of Poznan, Wrocław and Kraków is not accidental and results from the fact that the three cities are the leaders of place marketing in Poland. On the other hand, the biggest universities of these cities are some of the best and the most established in the country.
\end{abstract}

Key words: university marketing, city marketing, place marketing, cooperation, model approach

\section{INTRODUCTION}

Cities compete on the market, as do profit-oriented enterprises. Therefore, aiming at the satisfaction of citizens' needs, local authorities strive for the interest of such entities which, due to possessed resources, can stimulate the development of cities. The entities are not only national and foreign investors (entrepreneurs) but also institutions at regional, central and international level, tourists, current and potential citizens, students, etc. Due to the increasing awareness of the role and importance of image, the entities become the receivers of an offer prepared by local authorities and their subordinated employees. Therefore, an offer prepared by a city takes into account various, often different expectations. Universities more and more often are the offer's key element.

The analysis focuses on the functional connection between university marketing and city marketing. Therefore, the main aim of the article is to reconstruct the model of marketing cooperation of Poznan, Wrocław and Kraków 
and their biggest universities: the Adam Mickiewicz University, the Wrocław University of Technology and the Jagiellonian University. The use of the authorial, five-element model will be used to measure the level of the institutionalization of the cooperation. Moreover, it will show whether there is an area for a further, deep cooperation or its level may be deemed satisfactory. The research perspective adopted by the author has a theoretical and institutional character. The used model facilitates the synthetic presentation of the fragment of the reality in question, namely the marketing cooperation between the examined cities and universities, which results from the nature of the model and cannot be perceived as a mistake (cf. Glinkowska, 2010, p. 256).

The choice of Poznań, Wrocław and Kraków is not accidental and results from the fact that the three cities are the leaders of place marketing in Poland (Best Place, 2013, pp. 7-10). On the other hand, the biggest universities of these cities are some of the best and the most established in the country. The author's intention is not, however, to present the extent and scale of the real (maintained in practice) cooperation between cities and universities. The author's intention is, therefore, to analyze only the chosen aspects of their marketing activity resulting from the aim of the article, such as implemented strategic documents, organizational structures responsible for marketing activity and particular promotional activities.

Marketing is a sphere of cities' functioning which may combine, and very often does, the marketing activity of many various entities, not only universities. Comprehensive literature shows that there may be entities conducting sports or tourist activity (see: Lubowiecki-Vikuk, \& Basińska-Zych, 2011). Due to the huge possibilities to influence the behavior of clients - recipients resulting from using various communication channels, an important role may be, therefore, played by particular sports events or popular local sports teams (cf. Bodet, 2012; Theofilos, 2012). As Irving Rein and Ben Shields claim, the connection between sports marketing and place marketing is, therefore, crucial and has a great potential for application (see: Rein, \& Shields, 2006; cf. Kozma, 2012).

Taking into account the aim of article, which is the model assessment of the level of marketing institutionalization of the cooperation between the three chosen cities and three chosen universities, it discusses primarily these connections, although it also refers to the chosen aspects of the marketing cooperation between cities and sports units.

\section{PAPER STRUCTURE AND METHODS}

The article consists of two parts. The first, a theoretical one, presents the review of the most important approaches to city marketing and the marketing of universities. Moreover, it includes the author's discussion of the importance of using the models applied for the analyses of the complex social and economic reality. It also presents the authorial, five-element model of the cooperation of cities and universities. The second part of the article presents the results of the research devoted to the chosen aspects of marketing activities of, 
first, Poznań, Wrocław and Kraków and, second, the universities situated in the area of the cities in question.

For the sake of the article, various but complementary research methods will be used. Three methods will be dominant. The first one is a case study. It is based on the multi-factor analysis of a particular, individual process or phenomenon and enables one to draw conclusions which may be further applied in the analysis of similar processes and phenomena. The second method is a comparative one. Its cognitive value is crucial as it allows the author to determine and catalogue the similarities and differences between processes and phenomena. The third method is content analysis of documents and materials, among others.

\section{CITY AND UNIVERSITY MARKETING}

The marketing activity of cities, similar to universities, is a result of many various but closely related factors (see: Glinka, 2015, p. 255). A key role is played by the change of the classic concept of marketing developed for the sake of the functioning of commercial entities. The marketing orientation of the actions of public entities, whose aim is not to gain a measurable, economic profit but to satisfy particular social needs, is therefore an effect of the deepening and expanding of a classic, narrow understanding. Due to the change in the perception of the mechanisms of gaining resources (human, financial, organizational) public entities, including cities and universities, prepare an offer targeted at the various groups of clients - recipients.

The review of the literature shows that place marketing may be defined in many ways. The focus on a client - a recipient seems to be an element which links virtually all the presented approaches (see: O'Leary, \& Iredal, 1979, p. 156; Van den Berg, \& Braun, 1999, p. 993). For example, according to American Marketing Association (AMA) (2016), place marketing is "designed to influence target audiences to behave in some positive manner with respect to the products or services associated with a specific place".

The dynamic development of studies concerning the use of the marketing concept by cities, regions and countries intensifies the number of presented approaches and, hence, definitions. As a result, the concentration on the promotion aspect of place units loses in significance. Therefore, the chances and limits related to the use of promotion-mix (advertising, personal selling, sale promotion and public relations) are no longer the core of researchers' considerations (cf. Gold, \& Vard, 1995).

The change of the current view is accurately reflected by Philip Kotler's statement that "places need to be doing what business have been doing for years: strategic market planning" (Kotler, Haider, \& Rein, 1993, p. 79). The strictly promotional aspect of cities' activity gives way to an integrated approach which emphasizes not only the role of strategic planning but also the perspective of using marketing-mix: starting from $4 \mathrm{P}$ and $4 \mathrm{~L}$ understandings ending with their numerous, broadly-commented modifications (cf. Van den Berg, Klaasse, \& Van 
der Meer, 1990; Paddison, 1993; Ashworth, \& Voogd, 1994; Kotler, Asplund, Rein, \& Haider, 1999; Kotler, Hamlin, Rein, \& Haider, 2002).

The contemporary analyses and elaborations more and more often focus on a brand, which results in the rising popularity of the concept of place branding (cf. Hankinson, 2001; Kavaratzis, \& Ashworth, 2005; Iversen, \& Hem, 2008; Kavaratzis, 2009; Govers, \& Go, 2009; Dinnie, 2011). According to Seppo Ranisto (2003, p. 50), its usefulness results from the fact that "place brands resemble corporate umbrella brands and can benefit the value of a place's image". In Erik Braun's (2010, pp. 3-5) opinion, the importance of city branding increases due to the high level of internal differentiation of cities, services and products offered by them, as well as particular target groups.

According to Michalis Kavaratzis (2004, p. 66), the essence of the current place marketing is reflected in the philosophy of integrated approach, with branding as its obligatory element. Branding, based on the multi-channel process of communication with target groups, allows one to strengthen the reputation of a city and shape its positive image.

Figure 1 presents the dynamics of the development of place marketing concept. The figure may be treated as a continnum between an old, one-direction promotional activity and the contemporary, broad understanding of place marketing.

\section{Figure 1.}

City marketing interpretations

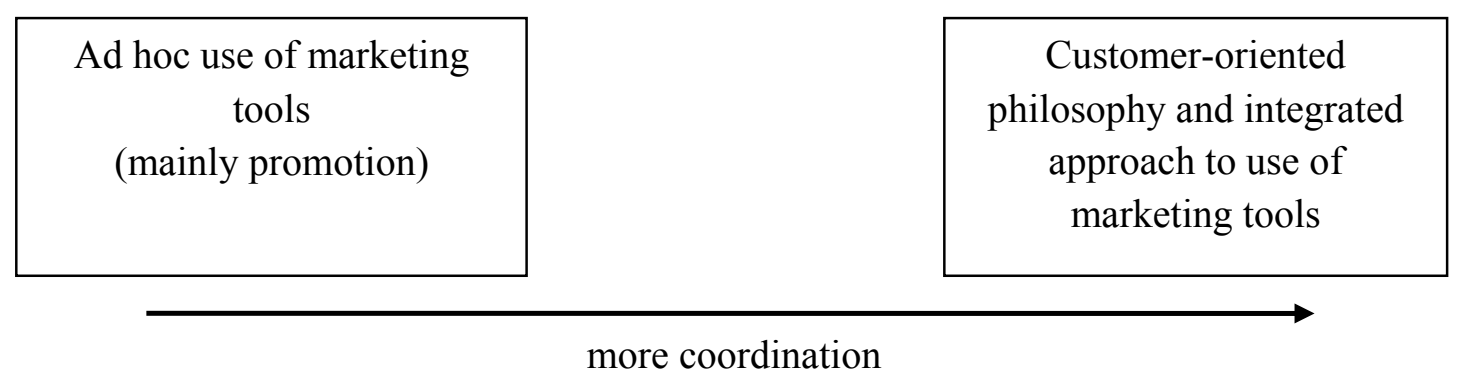

Source: the author's own compilation based on: Braun, 2008, p. 44.

According to Erik Braun (2008, p. 43), city marketing "is the coordinated use of marketing tools supported by a shared customer oriented philosophy, for creating, communicating, delivering, and exchanging urban offerings that have value for the city's customers and the city's community at large". It seems that the presented-above understanding, which corresponds to the definition proposed by M. Kavaratzis, fully reflects the specificity of the contemporary marketing activity of cities.

University marketing, similar to the activity of the place units competing at the market, is a subject of interest of many researchers (cf. Cochran, \& Dennis, 1983; Naudé, \& Ivy, 1999; Hemsley-Brown, \& Oplatka, 2006; Hammond, Harmon, \& Webster, 2007; Hayes, 2007). The review of comprehensive lite- 
rature shows that universities, like commercial units, focus on a client - a recipient. By creating a positive, desirable image, they engage increasing organizational and financial resources. Chris Chapleo (2010, p. 8). argues that "image and reputation of some universities have been argued to be more important factors than actual teaching quality".

Similar as in the case of cities, marketing activity is characterized by the integrated approach. Branding becomes its obligatory element. Gili S. Driori, Guiseppe Delmestri and Achim Oberg (2013, pp. 142-143) claim that "the reason to create a (recognizable and unique) brand is to establish a marketable feature, and such a feature is necessary under conditions of intensifying competition over resources (funding, renowned academics etc.) and consumers (students)".

Place and university marketing undoubtedly create two separate branches of knowledge and, hence, are the subject of interest of researchers representing various research perspectives. However, taking into account a functional aspect (planning and implementing marketing activities), they have a number of common features.

\section{COMPETING FOR TARGET GROUPS - TOGETHER OR SEPARATELY?}

The similar or the same (regarding students) target groups which academic and city authorities try to communicate with are an element which undoubtedly justifies the question concerning the potential of city and university cooperation.

Undoubtedly, potential and current students are the most important recipients of the universities' marketing activities. Obviously, the competing universities present their offer also to graduates, employers and all the entities which can finance the higher education sector. However, these are the students who, irrespective of the fact whether they function in the close surroundings of a university (the same city) or distant one (come from other city, region, country), constitute the group whose interest is particularly important for university authorities (Lewison, \& Hawes, 2007, p. 15).

The recipients of the cities' marketing activities also belong to various groups. Their number is the result of the decisions concerning to whom local authorities want to present their offer. Contrary to universities, it is difficult to determine the one dominant group of the recipients of the marketing of such local government units. It is especially difficult in the case of big cities, due to the fact that they expand and diversify their offer as they fulfill various functions. Table 1 presents the three groups of recipients whose needs and expectations are satisfied by an adequately prepared offer of a city. 
Table 1.

Chosen target groups of city marketing

\begin{tabular}{ll}
\hline Receivers & Expectations of a city offer \\
\hline Students & $\begin{array}{l}\text { a place having at its disposal an education offer: creating } \\
\text { opportunities for gaining quality education but also finding } \\
\text { employment fitting the acquired education }\end{array}$ \\
\hline Investors & $\begin{array}{l}\text { a place having at its disposal an investment offer: not only } \\
\text { (entrepreneurs) }\end{array}$ \\
& $\begin{array}{l}\text { a relevant infrastructural background but also a well-quali- } \\
\text { fied, educated workforce }\end{array}$ \\
\hline Citizens & $\begin{array}{l}\text { a place having at its disposal a comprehensive offer: cre- } \\
\text { ating favorable conditions for work, entertainment, as well } \\
\end{array}$ \\
& as education and upgrading qualifications
\end{tabular}

Source: the author's own compilation.

As results from the above compilation, all the groups of receivers treat universities and, hence, the opportunity of education as the criterion of sine qua non choice of a place, at first, to study, second, to invest and, third, to live. In the case of potential and current students, the key role is played, obviously, by a free access to higher education. Investors and entrepreneurs seek for well-educated, competent staff, while an element which attracts the attention of current and future citizens is the great opportunity of upgrading their qualifications (cf. Lewison, \& Hawes, 2007).

Table 2.

The benefits and restrictions of the marketing cooperation between cities and universities

\begin{tabular}{|c|c|}
\hline \multicolumn{2}{|l|}{ Marketing } \\
\hline Benefits & Restrictions \\
\hline $\begin{array}{l}\text { - gaining competitive } \\
\text { advantage over other cities/ } \\
\text { universities }\end{array}$ & $\begin{array}{l}\text { - the lack of experiences (models) concerning } \\
\text { the marketing cooperation between cities } \\
\text { and universities }\end{array}$ \\
\hline $\begin{array}{l}\text { - reciprocal strengthening/ } \\
\text { supplementing of the offers } \\
\text { targeted to the same groups } \\
\text { of receivers }\end{array}$ & $\begin{array}{l}\text { - the necessity of the harmonization and coordi- } \\
\text { nation of the actions conducted henceforth in dif- } \\
\text { ferent time perspectives, with the use of various } \\
\text { marketing tools, within incongruent budgets }\end{array}$ \\
\hline $\begin{array}{l}\text { - reducing the costs of con- } \\
\text { ducted marketing activities }\end{array}$ & $\begin{array}{l}\text { - the lack of stability of the balance of power in } \\
\text { the local political arena }\end{array}$ \\
\hline
\end{tabular}

Source: the author's own compilation.

As is emphasized by Justyna Adamczuk (2015, p. 196), the opportunity of shaping an internally coherent, positive image of a city or university is the main premise in favor of the bilateral marketing cooperation. Although many restrictions (see: Table 2), the synergy of place marketing and university marketing is therefore a desirable dimension of the development of the relations between the authorities of cities and universities (cf. Domański, 2011). 


\section{MODELS AND THEIR USEFULNESS}

The representatives of various scientific disciplines make an effort to create, test and modify research models. The models, treated as the simplified representations of a particular (existing or potential) part of reality, are used to determine its chosen elements, crucial for the research aim.

According to Russell L. Ackoff (1969, p. 142), "the simplicity of the models (...) results from the fact that they take into account only the properties (...) which are relevant in a particular case". They intentionally emphasize only the chosen features and, at the same time, intentionally ignore the ones which could reveal the inadequacy of an analysis. As they do not meet the requirement of isomorphism, they constitute only a general, formal image of a problem (Neal, \& Shone, 1982, p. 122).

The models are more and more often applied in the analyses of social and economic reality which is complicated, not only multi-subject and multi-dimensional but also subject to ongoing transformations. Therefore, the representatives of social sciences (such as sociology, political science, public policy, European studies, international relations), economics and management make an attempt to construe the models. As Andrzej Jabłoński (2010, p. 9) emphasizes, the aim of using the models is to "show the real nature of a phenomenon in question which constitutes a research subject analyzed from various theoretical perspectives".

The compilation and comparison of, on the one hand, the marketing of Poznań, Wrocław and Kraków and, on the other hand, the marketing of the biggest universities functioning within the administrative borders of those cities requires adopting some simplifications. Assuming that both cities and universities conduct intensive marketing activities targeted at the same groups of recipients, one may adopt that they fit into a cooperation model. The presented below proposal of an analytic model has a fully authorial character. Therefore, it needs to be discussed in detail.

The main criterion which allows one to define a cooperation model is the criterion of the institutionalization of the contacts developed between cities (local authorities) and universities (academic authorities).

The specific criteria allow determining if:

1. at strategic level:

a) the documents adopted by local authorities include universities in the marketing activities of cities,

b) the documents adopted by academic authorities include cities in the marketing activities of universities,

c) the documents adopted both by local authorities and academic authorities program marketing activities;

2. at operational level:

d) are there any entities (the organizational units of municipalities or universities) which coordinate common marketing activities,

e) are there any common marketing activities.

The fulfillment of all the five criteria allows one to state that the cooperation 
Journal of Education Culture and Society No. 1_2017

model has a fully institutionalized (formalized) character. In turn, the failure in fulfilling any of the criteria is the evidence of its non-institutionalized character (see: Figure 2).

\section{Figure 2.}

The model of the institutionalization of marketing cooperation.

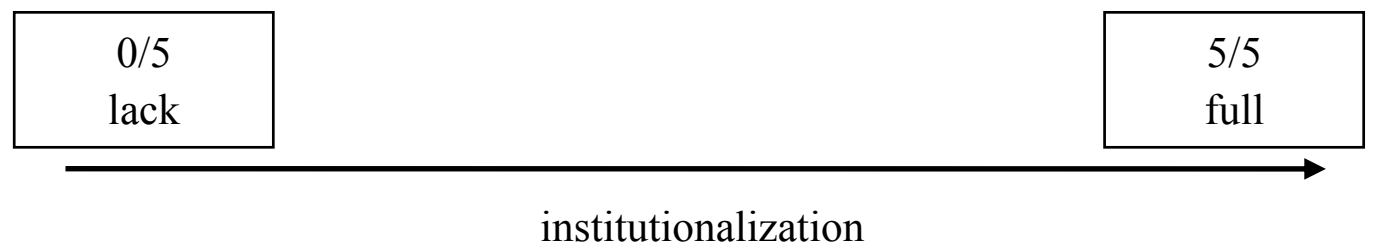

Source: the author's own compilation.

The above model, although it is the author's proposal, is not, obviously, the only one possible approach to the cooperation developed between a city and universities. In this sense, it has an authorial character and may be treated as a proposal to create the particular theoretical framework for bilateral cooperation.

\section{POZNAŃ, WROCŁAW, KRAKÓW - ACADEMIC CITIES}

Undoubtedly, Poznań, Wrocław and Kraków are academic cities. As results from Table 3, each of the cities creates an opportunity to study at more than twenty universities. There are not only public universities but also private and Catholic ones.

\section{Table 3.}

The universities of Poznań, Wrocław and Kraków

\begin{tabular}{llllll}
\hline City & $\begin{array}{l}\text { The } \\
\text { number } \\
\text { of uni- } \\
\text { versities }\end{array}$ & & including & & $\begin{array}{l}\text { The biggest univer- } \\
\text { sity (in terms of the } \\
\text { number of students) }\end{array}$ \\
\cline { 3 - 6 } & & $\begin{array}{l}\text { public } \\
\text { universities }\end{array}$ & $\begin{array}{l}\text { private } \\
\text { universities }\end{array}$ & $\begin{array}{l}\text { Catholic } \\
\text { university }\end{array}$ \\
\hline Poznań & 24 & 8 & 16 & - & $\begin{array}{l}\text { Adam Mickiewicz } \\
\text { University }\end{array}$ \\
\hline Wrockaw & 25 & 9 & 15 & 1 & $\begin{array}{l}\text { Wrocław University } \\
\text { of Technology }\end{array}$ \\
\hline Kraków & 21 & 10 & 9 & 2 & $\begin{array}{l}\text { Jagiellonian } \\
\text { University }\end{array}$ \\
\hline TOTAL & 70 & 27 & 40 & 3 & - \\
\hline
\end{tabular}

Source: the author's compilation on the basis of: WybierzStudia, 2016; GUS, 2013, p. 29. 
The biggest universities of Poznań, Wrocław and Kraków are: the Adam Mickiewicz University, the Wrocław University of Technology and the Jagiellonian University with the number of students: 43422, 33530 and 41818, respectively (UAM, 2016; PWr, 2016; UJ, 2016).

Table 4.

The programming of the marketing activities of Poznań, Wroctaw and Kraków

\begin{tabular}{lll}
\hline City & Strategic document & $\begin{array}{l}\text { Specialized strategic } \\
\text { document }\end{array}$ \\
\hline Poznań & $\begin{array}{l}\text { - Development Strategy for the City of } \\
\text { Poznań up to 2013. Update in 2013 }\end{array}$ & $\begin{array}{l}\text { Promotion Strategy of } \\
\text { Poznań Brand }\end{array}$ \\
\hline Wrocław & $\begin{array}{l}\text { - Strategy - Wrocław in the perspective } \\
\text { of 2020 plus }\end{array}$ & lack \\
& - The Tourist Program of Wrocław & \\
\hline Kraków & $\begin{array}{l}\text { - Development Strategy of Kraków } \\
\text { - Tourism Development Strategy in } \\
\\
\text { Kraków for 2014-2020 }\end{array}$ \\
\hline
\end{tabular}

Source: the author's own compilation on the basis of: Poznań, 2016; Wrocław, 2016; Kraków, 2016. As of 18th of March 2016.

\section{Table 5.}

Universities in the marketing of Poznań, Wrocław and Kraków according to strategic documents

\begin{tabular}{ll}
\hline City & Vision of a city and assumptions \\
\hline Poznań & - 'Strong academic centre with European dimension' \\
& - 'Poznań has a huge academic and scientific potential; it is an \\
& ideal place for young and ambitious people' \\
& - 'Poznań is a city of occupational chances for the professionals; \\
& it is a city of attractive employers and expansively developing \\
& business - it is a strong centre of economy based on knowledge' \\
\hline Wrocław & - 'Domestic and foreign promotion of Wrocław as an attractive \\
& study destination' \\
& - 'Striving for the creation of a European research centre' \\
\hline Kraków & - 'Kraków (...) the centre of a modern economy based on the \\
& scientific and cultural potential'
\end{tabular}

Source: the author's own compilation on the basis of: Poznań, 2016; Wrocław, 2016; Kraków, 2016. As of 18th of March 2016.

According to the report 'TOP promotion of Polish cities, districts and region 2013' (Pol. ‘TOP promocji polskich miast, powiatów i regionów 2013’) , Poznań, Wrocław and Kraków are the leaders of place marketing in Poland (Best Place, 2013, pp. 7-10). It does not depend on whether the conducted actions result from the specialized strategic documents (strategies or marketing plans) pre- 
pared and adopted by local authorities or not. Table 4 shows that only one city, Poznań, has such a document at its disposal.

Students, investors (entrepreneurs) and citizens are the receivers of the marketing activities conducted by all three cities. Therefore, an opportunity to study and upgrade qualifications is an important element of an offer targeted at them. As it is presented in the compilation presented below, the official strategic documents of Poznan, Wrocław and Kraków indicate that it is necessary to conduct the marketing activities which use the education potential of local universities. It is visible in the visions of cities formulated by local authorities.

\section{THE BIGGEST UNIVERSITIES OF POZNAN̂, WROCŁAW AND KRAKÓW}

The universities, like the cities, also program their activities. As shown in Table 6 each of the universities in question - the Adam Mickiewicz University, the Wrocław University of Technology, the Jagiellonian University, has a strategic document.

As seen below, the universities delineate their vision of development in relation to the immediate surroundings, which are Poznan, Wrocław and Kraków. According to the first document, the Adam Mickiewicz University is 'an integral part of the city'. The Development Strategy for Wrocław University of the Technology indicates for the location of the university 'in the centre of one of the most attractive cities in Europe'. The Jagiellonian University wants to be perceived as not only , an attractive place to study', but also 'to trigger creativity and realize aspirations'. Its realization can only take place in cooperation with the city.

\section{Table 6.}

City in the future vision of the Adam Mickiewicz University, the Wroctaw University of Technology, the Jagiellonian University according to strategic documents.

\begin{tabular}{|c|c|c|}
\hline University & Strategic document & The vision of the university \\
\hline $\begin{array}{l}\text { Adam Mickiewicz } \\
\text { University }\end{array}$ & $\begin{array}{l}\text { - Strategy of Adam } \\
\text { Mickiewicz University } \\
\text { Development for 2009- } \\
\text { 2019. Amendment }\end{array}$ & $\begin{array}{l}\text { - 'The university is an inte- } \\
\text { gral part of the city, which } \\
\text { makes the academic Poznan } \\
\text { outstanding against Poland'. }\end{array}$ \\
\hline $\begin{array}{l}\text { Wrocław } \\
\text { University of } \\
\text { Technology }\end{array}$ & $\begin{array}{l}\text { - Strategy of Wrocław } \\
\text { University of Techno- } \\
\text { logy Development }\end{array}$ & $\begin{array}{l}\text { - 'University located in the } \\
\text { centre of one of the most } \\
\text { attractive cities in Europe' }\end{array}$ \\
\hline $\begin{array}{l}\text { Jagiellonian } \\
\text { University }\end{array}$ & $\begin{array}{l}\text { - Strategy of Jagiellonian } \\
\text { University Develop- } \\
\text { ment for 2014-2020 }\end{array}$ & $\begin{array}{l}\text { - 'An attractive place to } \\
\text { study, trigger creativity and } \\
\text { realize aspirations' }\end{array}$ \\
\hline
\end{tabular}

Source: the author's own compilation on the basis of: UAM, 2013; PWr, 2013; UJ, 2014. 


\section{CITIES AND UNIVERSITIES - TOWARDS REAL COOPERATION?}

A key role in the practical implementation of marketing activities is played by specialized entities that are able not only to organize properly the actions but also coordinate them. Especially when considering the actions conducted within the multilateral cooperation. The efficient and effective marketing cooperation cannot therefore include only the strategic level (i.e. developing long-term strategic documents). An important role is played by the operational level at which partial, short-term decisions are made and concrete projects and initiatives are agreed. In the case of cities and universities, relevant organizational units are the entities that implement the assumptions of strategic documents.

As shown in Table 7, all the cities in question created the organizational units which are responsible for the implemented marketing activities. In Poznan it is the President's Office, in Wrocław - the Office of City Promotion and Tourism, and in Kraków - the Department of Promotion and Tourism. Although the names of the organizational units indicate chosen aspects of marketing activity (e.g. promotion) or target groups (in case of Wrocław and Kraków tourists are strongly emphasized), in reality they coordinate the integrated activities targeted at all groups, including students, among others.

Table 7.

City marketing and university marketing - operational level

\begin{tabular}{|c|c|c|c|}
\hline $\begin{array}{l}\text { City (university)/ } \\
\text { organizational } \\
\text { unit }\end{array}$ & $\begin{array}{l}\text { Unit of municipal } \\
\text { council }\end{array}$ & $\begin{array}{l}\text { Unit of } \\
\text { university }\end{array}$ & $\begin{array}{l}\text { An example of a } \\
\text { common marke- } \\
\text { ting activities }\end{array}$ \\
\hline $\begin{array}{l}\text { Poznań } \\
\text { (Adam Mickie- } \\
\text { wicz Univeristy) }\end{array}$ & $\begin{array}{l}\text { - Office of the President } \\
\text { - City Development } \\
\text { Department (program } \\
\text { 'Academic and Scien- } \\
\text { tific Poznań') }\end{array}$ & $\begin{array}{l}\text { - Department } \\
\text { of Promotion } \\
\text { and Marketing }\end{array}$ & $\begin{array}{l}\text { - promotional } \\
\text { campaign 'Study } \\
\text { in Poznan' }\end{array}$ \\
\hline $\begin{array}{l}\text { Wrocław } \\
\text { (Wrocław } \\
\text { University of } \\
\text { Technology) }\end{array}$ & $\begin{array}{l}\text { - Office of City Promo- } \\
\text { tion and Tourism } \\
\text { - Office for University } \\
\text { Cooperation } \\
\text { (Wrocław Academic } \\
\text { Center) }\end{array}$ & $\begin{array}{l}\text { - Department } \\
\text { of Market- } \\
\text { ing and } \\
\text { Promotion }\end{array}$ & $\begin{array}{l}\text { - information } \\
\text { book }\end{array}$ \\
\hline $\begin{array}{l}\text { Kraków } \\
\text { (Jagiellonian } \\
\text { University) }\end{array}$ & $\begin{array}{l}\text { - Department of Pro- } \\
\text { motion and Tourism }\end{array}$ & $\begin{array}{l}\text { - Department } \\
\text { of Promo- } \\
\text { tion and } \\
\text { Information }\end{array}$ & $\begin{array}{l}\text { - consortium } \\
\text { 'Study in } \\
\text { Krakow' }\end{array}$ \\
\hline
\end{tabular}

Source: the author's own compilation on the basis of: Poznań, 2016a; Wrocław, 2016a; Kraków, 2016a.; UAM, 2016a; PWr, 2016a; UJ, 2016a. 
Related tasks are being implemented by the organizational units of the universities. Within the structure framework of the Adam Mickiewicz University there is the Department of Promotion and Marketing, the Wrocław University of Technology - the Department of Marketing and Promotion, and the Jagiellonian University - the Department of Promotion and Information.

As seen above, the cooperation between a city and university results in specific marketing (or promotional) activities. They include the projects and initiatives involving the variety of organizational and financial resources. The examples are: the issuing of an information book (as is the case of Wrocław), the organization of promotional campaigns (Poznań) or the creation of consortium whose task is to create a positive, desired offer of both the city and the university (Kraków).

The analysis of the above compilation shows that although both the cities and the universities have the organizational units that are responsible for conducting, also in the form of co-operation, marketing activities, the local authorities of two out of the three cities decided to create additional, specialized entities, focused on the development of relations with the academic environment. In the case of the national leader of place marketing, the tasks of this entity are executed by the City Development Department. On the other hand, in the case of Wrocław it is the Wrocław Academic Centre.

\section{CONCLUSION}

Due to the competition for human, financial and organizational resources, the public entities, which are not oriented at gaining a measurable, economic profit, conduct marketing activities. Therefore, both cities and universities, treated as such entities, strive for the interest of many groups of receivers. They make an effort to prepare an attractive marketing offer which is capable of satisfying the receivers' needs and expectations.

The students (both potential and current) are the group whose interest is especially important for local and academic authorities and, hence, they try to attract students' attention. It is therefore an impulse to maintaining the marketing cooperation of cities and universities which can be developed on a different scale and to various extents.

The compilation and comparison of the chosen aspects of the marketing activity of Poznań, Wrocław and Kraków and their biggest universities: the Adam Mickiewicz University, the Wrocław University of Technology and the Jagiellonian University show that the cooperation between a city and universities exists. What is more, it allows one to positively verify the cooperation model presented by the author in the previous part of the article. It is justified by the data included in Table 8 .

The criteria presented above show that the cooperation of cities and universities fulfils four out of five criteria (4/5). Firstly, Poznan, Wrocław and Kraków have at their disposal the official strategic documents which emphasize the role of universities in the preparation of a marketing offer 
by local authorities. Secondly, the agreed, adopted and implemented official strategic documents of the Adam Mickiewicz University, the Wrocław University of Technology and the Jagiellonian University place marketing activities of the university in broader surroundings created by cities. Thirdly and fourthly, both local and academic authorities decided upon the creation of organizational units which are responsible for conducting common marketing activities. The various enterprises targeting the potential and current students of Poznań, Wrocław and Kraków universities are the signs of cooperation.

\section{Table 8.}

The model of marketing cooperation between universities and cities

\begin{tabular}{llll}
\hline Criterion & Poznań & Wrocław & Kraków \\
\hline 1. City strategies & $1 / 1$ & $1 / 1$ & $1 / 1$ \\
\hline 2. University strategies & $1 / 1$ & $1 / 1$ & $1 / 1$ \\
\hline 3. Common (city and university) strategies & $0 / 1$ & $0 / 1$ & $0 / 1$ \\
\hline 4. Organizational units (of city; university) & $(1 / 1 ; 1 / 1)$ & $(1 / 1 ; 1 / 1)$ & $(1 / 1 ; 1 / 1)$ \\
\hline 5. Common marketing activities & $1 / 1$ & $1 / 1$ & $1 / 1$ \\
\hline Total: & $4 / 5$ & $4 / 5$ & $4 / 5$ \\
\hline
\end{tabular}

Source: the author's own compilation.

As results from Table 8, one out of four criteria is not fulfilled at all. In other words, none of the examined cities has a strategic marketing document which is prepared in cooperation with the university defines the objectives and directions of the common activities. Independently, these activities are conducted in practice. The examined cooperation model cannot be therefore named as fully institutionalized. Therefore, it may be stated that there is a further area for the development of bilateral marketing cooperation.

However, there is one, additional element which has a key importance for the verification of the model, namely, the specialized organizational units of municipalities which are responsible for the complex organization of the cooperation between a city and universities. The units (in bold and underlined in Table 8) coordinate the development of contacts in many areas, including marketing. Their inclusion in the structure of municipalities may mean that the cities, due to the possessed human, financial and organizational resources, dominate, in a way, the course and scope of marketing cooperation. The conclusion, however, requires further, in-depth research conducted in a broader scale and using other research methods.

Obviously, universities are not the only entities which may cooperate with cities by conducting marketing activity. The potential of developing bilateral marketing cooperation lies in e.g. football clubs which, functioning in the area of cities, aim at the same target groups as cities. The possibilities to cooperate result also from the huge potential of clubs to create the identity and image of place (Shobe, 2006, p. 262). 
In case of Poznań, Wrocław and Kraków, the key role is played by football clubs: Lech Poznań, Śląsk Wrocław and Cracovia, respectively. It is due to the huge popularity of football in Poland, both, when it comes to people actively playing football and belonging to clubs, as well as persons following football matches and cheering chosen teams on (GUS, 2012). Although all of the three clubs take part in the football matches of the Polish first league (Ekstraklasa, 2016), in their case the institutionalization of marketing cooperation is just partial.

Table 9.

The model of marketing cooperation between universities and football clubs

\begin{tabular}{llll}
\hline Criterion & Poznań & Wrocław & Kraków \\
\hline 1. City strategies & $1 / 1$ & $1 / 1$ & $1 / 1$ \\
\hline 2. Football club strategies & $0 / 1$ & $0 / 1$ & $0 / 1$ \\
\hline 3. Common (city and football club) strategies & $0 / 1$ & $0 / 1$ & $0 / 1$ \\
\hline 4. Organizational units (of city; football club) & $(1 / 1 ; 0 / 1)$ & $(1 / 1 ; 0 / 1)$ & $(1 / 1 ; 0 / 1)$ \\
\hline 5. Common marketing activities & $1 / 1$ & $1 / 1$ & $1 / 1$ \\
\hline Total: & $2 / 5$ & $2 / 5$ & $2 / 5$ \\
\hline
\end{tabular}

Source: the author's own compilation.

The official city strategies suggest, as a matter of fact, that sport constitutes an element of creating the image of Poznań, Wrocław and Kraków (Poznań, 2016; Wrocław, 2016; Kraków 2016). What is more, there are organizational units in the city municipalities being responsible for the commonly implemented marketing activities. However, the institutionalization of the marketing cooperation between cities and football clubs embraces fully barely two criteria (2/5). Therefore, as compared to universities, the level is much lower.

The comparison of Poznań, Wrocław and Kraków and their biggest universities allows one to claim that marketing cooperation, in the form of a model, proceeds in different ways. All of the three cities and universities create not only formal and legal (strategic documents) but also organizational (units in the structure of municipalities and universities) basis for the development of bilateral contacts. Despite the lack of common strategic documents, the cities and universities conduct common marketing activities.

Obviously, the solutions adopted within the existing city and university strategies are not detailed and sufficient. Although city strategies emphasize the role of universities and vice versa, the lack of detailed integrated definition of common goals, target groups and, hence, commonly used marketing tools, points to the insufficient level of the institutionalization of cooperation.

The proposed model certainly simplifies the fragment of reality in question, in this case the marketing cooperation of cities and universities, which results from its nature. The use of this model in the analysis of other cases (cities which are not the leaders of place marketing and universities which are not the best in the country) creates an opportunity of its verification but also, further possible modification and elaboration. 


\section{REFERENCES:}

[1] Ackoff, R. L. (1962). Decyzje optymalne w badaniach stosowanych [Optimal decisions in the applied research].Warszawa: PWN.

[2] AMA (2016). Place marketing. American Marketing Association Definition. Retrieved from https://www.ama.org/resources/Pages/Dictionary.aspx?dLetter=P.

[3] Ashworth, G. J., \& Voogd, H. (1994). Marketing and place promotion. In: J. R. Gold \& S. V. Ward (Eds.). Place Promotion: The Use of Publicity and Marketing to Sell Towns and Regions (pp. 38-52). Chichester: John Wiley \& Sons.

[4] Berg, L. van den, Klaassen, L., \& Meer, J. van der (1990). Marketing Metropolitan Regions. Rotterdam: European Institute for Comparative Urban Research.

[5] Berg, L. van den, \& Braun, E. (1999). Urban Competitiveness, Marketing and the Need for Organising Capacity. Urban Studies, 36, 987-999.

[6] Best Place (2013). TOP promocji polskich miast, powiatów i regionów 2013 [TOP promotion of Polish cities, counties and regions in 2013]. Warszawa: Best Place - Europejski Instytut Marketingu Miejsc.

[7] Bodet, G. (2012). International Place Branding through Sporting Events: a British Perspective of the 2008 Beijing Olympics. European Sport Management Quarterly, 12, 4, 357-374.

[8] Braun, E. (2008). City Marketing. Towards a Integrated Approach. Rotterdam: Erasmus University Rotterdam.

[9] Braun, E. (2010). Towards an Integrated Approach for Place Brand Management. Paper presented at 50th European Regional Science Association Congress. Retrieved from www-sre. wu.ac.at/ersa/ersaconfs/.../ERSA2010finalpaper181.pdf.

[10] Cochran, T. R. \& Dennis, D. H. (1983). Assessing the Image of a University. The Journal of College Admissions, 28, 29-34.

[11] Dinnie, K. (Ed.) (2011). City Branding. Theory and Cases. Basingstoke, Hampshire: Palgrave Macmillan.

[12] Domański, T. (2011). Rola uniwersytetów w promocji polskich miast i regionów - nowe wyzwania strategiczne [The role of universities in promoting Polish cities and regions - the new strategic challenges]. In: T. Domański (Ed.). Marketing akademicki. Rola uniwersytetów $\mathrm{w}$ promocji miast i regionów [Academic marketing. The role of universities in the promotion of cities and regions] (pp. 15-32). Łódź: Wydawnictwo Uniwersytetu Łódzkiego.

[13] Drori, G. S., Delmestri, G., \& Oberg, A. (2013). Branding the University: Relational Strategy of Identity Construction in a Competitive Field. In: L. Engwall \& P. Scott (Eds.). Trust in Higher Education Institutions (pp. 134-147). London: Portland Press.

[14] Ekstraklasa (2016). Ekstraklasa. Kluby [First league. Football clubs]. Retrieved from http:// www.ekstraklasa.org/\#.

[15] Glinka, K. (2015). Cooperation within network? City marketing in the network perspective. In: R. Wiszniowski, \& K. Glinka (Eds.). New Public Governance in the Visegrád Group (V4) (pp. 250-263). Torun: Wydawnictwo Adam Marszałek.

[16] Glinkowska, B. (2010). Modelowanie w procesach usprawniania organizacji - uwagi teoretyczno-metodyczne [Modeling in the processes of organization improvement - theoretical and methodological remarks]. Acta Universitatis Lodziensis. Folia Oeconomica, 234, 255-264.

[17] Gold, J. R., \& Ward, S. V. (Eds.) (1995). Place Promotion: The Use of Publicity and Marketing to Sell Towns and Regions. Chichester: Wiley \& Sons.

[18] Govers, R., \& Go, F. (2009). Place Branding. Glocal, Virtual and Psychical Identities, Constructed, Imagined and Experienced. Basingstoke, Hampshire: Palgrave Macmillan.

[19] GUS (2012). Piłka nożna w badaniach statystycznych [Football in statistic datas]. Retrieved from stat.gov.pl/cps/rde/xbcr/gus/KTS_pilka_nozna_w_badaniach_statystycznych.pdf.

[20] GUS (2013). Szkoły wyższe i ich finanse w 2012 r. [Universities and their finances in 2012]. Warszawa: Główny Urząd Statystyczny.

[21] GUS (2014). Miasta w liczbach 2012 [Cities in numbers of 2012]. Warszawa: Główny Urząd Statystyczny.

[22] GUS (2014a). Miasta największe pod względem liczby ludności [The largest city in terms of population]. Retrieved March 18, 2016, http://stat.gov.pl/statystyka-regionalna/ rankingi-statystyczne/miasta-najwieksze-pod-wzgledem-liczby-ludnosci/. 
[23] Hammond, K., Harmon, H., \& Webster, R. (2007). University performance and strategic marketing: an extended study. International Journal of Public Sector Management, 19, 4, 436-459.

[24] Hemsley-Brown, J., \& Oplatka, I. (2006). Universities in a competitive global marketplace. A systematic review of the literature on higher education marketing. International Journal of Public Sector Management, 19, 4, 316-338.

[25] Hankinson, G. (2001). Location branding: A study of the branding practices of 12 English cities, Journal of Brand Management, 9, 2, 127-142.

[26] Hayes, T. (2007). Delphi study of the future of marketing of higher education. Journal of Business Research, 60, 9, 927-931.

[27] Iversen, N. M., \& Hem, L. E. (2008). Provenance associations as core values of place umbrella brands. European Journal of Marketing, 42, 5/6, 603-626.

[28] Jabłoński, A. (2010). Czym jest teoria w politologii? Teoria polityki: między nauką a interpretacją. Referat wygłoszony na Ogólnopolskiej Konferencji Naukowej ‘Czym jest teoria w politologii?' Poznań, 12.05.2010 r. [What is a theory in political science? The theory of politics: between the science and the interpretation. Paper presented at the National Scientific Conference 'What is a theory in political science?', Poznań, May 5, 2010]. Retrieved from wnpid. amu.edu.pl/attachments/787_Prof.\%20Blok\% 20-\%20referat.pdf.

[29] Kavaratzis, M. (2004). From city marketing to city branding: Towards a theoretical framework for developing city brands. Place Branding, 1, 1, 58-73.

[30] Kavaratzis, M., \& Ashworth, G. J. (2005). City branding: an effective assertion of identity or a transitory marketing trick? Tijdschrift voor Economische en Sociale Geografie, 96, 5, 506-514.

[31] Kavaratzis, M. (2009). Cities and their brands: Lessons from corporate branding. Place Branding and Public Diplomacy, 5, 1, 26-37.

[32] Kotler, P., \& Levy, S. J. (1969). Broadening of the Concept of Marketing. Journal of Marketing, 33, 10-15.

[33] Kotler, P., Haider, D. H., \& Rein, I. (1993). Marketing Places: Attracting Investment, Industry and Tourism to Cities, States and Nations. New York: The Free Press.

[34] Kotler, P., Asplund, C., Rein, I., \& Haider, D. H. (1999). Marketing Places Europe: How to Attract Investments, Industries, Residents and Visitors to Cities, Communities, Regions and Nations in Europe. London: Pearson Education Limited Harlow, Financial Times Prentice Hall.

[35] Kotler, P., Hamlin, M. A., Rein, I. \& Haider, D. H. (2002). Marketing Asian Places Attracting Investment, Industry and Tourism to Cities, States and Nations. Singapore: John Wiley \& Sons.

[36] Kozma, G. (2012). Sport as an Element in the Place Branding Acivities of the Local Government. GeoJournal of Toursim and Geosites, 2, 6, 133-143.

[37] Kraków (2016). Rozwój miasta [City development]. Retrieved from https://www.bip. krakow.pl/?bip_id=1\&mmi=6.

[38] Kraków (2016a). Urząd Miasta Krakowa [The City Council of Kraków]. Retrieved from https:/ / www.bip.krakow.pl/?mmi=32.

[39] Lewison, D. M. \& Hawes, J. M. (2007). Student Target Marketing Strategies for Universities. Journal of College Admission, Summer, 14-19.

[40] Lubowiecki-Vikuk, A. P. \& Basińska-Zych, A. (2011). Sport and Tourism as Elements of Place Branding A Case Study on Poland. Journal of Tourism Challenges and Trends, 4, 2, 33-52.

[41] Merrilees, B., Miller, D. \& Herington, C. (2012). Multiple stakeholders and multiple city brand meanings. European Journal of Marketing, 46, 7-8, 1032-1047.

[42] Naudé, P. \& Ivy, J. (1999). The marketing strategies of universities in the United Kingdom. International Journal of Educational Management, 13, 3, 126-136.

[43] O'Leary, R. \& Iredale, I. (1976). The marketing concept: quo vadis? European Journal of Marketing, 10, 3, 146-157.

[44] Paddison, R. (1993). City Marketing, Image Reconstruction and Urban Regeneration. Urban Studies, 30, 2, 339-350.

[45] Poznań (2016). Biblioteka dokumentów [Library of documents]. Retrieved from https:// www.bip.krakow.pl/?bip_id=1\&mmi=6.

[46] Poznań (2016a). Struktura organizacyjna miasta Poznania [The organizational structure of Poznań City]. Retrieved from http://bip.poznan.pl/bip/struktura-organizacyjna-miastapoznania,doc,293/. 
[47] PWr (2013). Strategia Rozwoju Politechniki Wrocławskiej [Strategy of Wrocław University of Technology Development]. Retrieved from http://www.portal.pwr.wroc.pl/plan_ rozwoju,241.dhtml.

[48] PWr (2016). Fakty i liczby [Facts and numbers]. Retrieved fromhttp://www.portal.pwr. wroc.pl/fakty,241.dhtml.

[49] PWr (2016a). Struktura uczelni [Structure of the university]. Retrieved from http://www. portal.pwr.wroc.pl/struktura_uczelni.dhtml.

[50] Rainisto, S. K. (2003). Success factors of place marketing. A study of place marketing practices in northern Europe and the United States. Helsinki: Helsinki University of Technology.

[51] Rein, I. \& Shields, B. (2006). Place branding sports: Strategies for differentiating emerging, transitional, negatively viewed and newly industrialised nations. Place Branding and Public Diplomacy, 3, 1, 73-85.

[52] Shobe, H. (2006). Place, Sport and Globalization: Making sense of la marca Barça. Treballs de la Societat Catalana de Geografia, 61-62, 259-276.

[53] Theofilos, P. (2012). The Place Branding of Istanbul for the Olympic Games of 2020. PODIUM Sport, Leisure and Tourism Review, 1, 1, 88-100.

[54] UAM (2013). Strategia Rozwoju Uniwersytetu Adama Mickiewicza w Poznaniu na lata 20092019 [Strategy of Adam Mickiewicz University Development for 2009-2019. Amendment]. Retrieved from https:/ / amu.edu.pl/dzialalnosc/o-uam/dokumenty-strategiczne-uczelni.

[55] UAM (2016). Stan zatrudnienia i liczba studiujących [The number of employees and the number of students]. Retrieved from https://bip.amu.edu.pl/bip/stan-zatrudnienia-iliczba-studiujcych-w-uam/stan-zatrudnienia-i-liczba-studiujacych-w-uniwersytecie-im.adama-mickiewicza-w-poznaniu.

[56] UAM (2016a). Struktura [Structure]. Retrieved from https://amu.edu.pl/s2/_struktura.

[57] UJ (2014). Strategia Rozwoju Uniwersytetu Jagiellońskiego w latach 2014-2020 [Strategy of Jagiellonian University Development for 2014-2020]. Retrieved from http:/ / www.uj.edu.pl/ uniwersytet-z-collegium-medicum/strategia-rozwoju.

[58] UJ (2016). Statystyki [Statistics]. Retrieved from http://www.uj.edu.pl/uniwersytet-zcollegium-medicum/statystyki.

[59] UJ (2016a). Struktura administracji [The administration structure]. Retrieved from http:// www.uj.edu.pl/pl_PL/struktura/administracja.

[60] Ward, S. (1998). Selling Places: The Marketing and Promotion of Towns and Cities 1850-2000. London: E \& FN Spon.

[61] Wrocław (2016). Programy, projekty i inne zamierzenia [Programs, projects and onther plans]. Retrieved from http:/ / bip.um.wroc.pl/artykul/330/5367/programy-projekty-i-inne -zamierzenia.

[62] Wrocław (2016a). Departamenty, wydziały, biura [Departments, faculties, offices]. Retrieved from , http:/ / bip.um.wroc.pl/artykuly/198/departamenty-wydzialy-biura.

[63] WybierzStudia (2016). Wybierz studia [Choose studies]. Retrieved from http://wybierzstudia.nauka.gov.pl/. 